\title{
Impact of Ozone Valley over the Tibetan Plateau on the South Asian High in CAM5
}

\author{
Zhenkun Li, ${ }^{1}$ Hao Qin, ${ }^{2}$ Dong Guo, ${ }^{2}$ Shunwu Zhou, ${ }^{2}$ Ying Huang, \\ Yucheng Su, ${ }^{2}$ Linwei Wang, ${ }^{3}$ and Yang Sun ${ }^{2}$ \\ ${ }^{1}$ Shanghai Climate Center, Shanghai 200030, China \\ ${ }^{2}$ Key Laboratory of Meteorological Disaster, Ministry of Education (KLME)/Joint International Research Laboratory of Climate and \\ Environment Change (ILCEC)/Collaborative Innovation Center on Forecast and Evaluation of Meteorological Disasters \\ (CIC-FEMD), Nanjing University of Information Science \& Technology, Nanjing 210044, China \\ ${ }^{3}$ Shanghai Public Meteorological Service Center, Shanghai 200030, China
}

Correspondence should be addressed to Dong Guo; dongguo@nuist.edu.cn

Received 22 May 2017; Revised 21 July 2017; Accepted 6 August 2017; Published 26 September 2017

Academic Editor: Julio Diaz

Copyright (C) 2017 Zhenkun Li et al. This is an open access article distributed under the Creative Commons Attribution License, which permits unrestricted use, distribution, and reproduction in any medium, provided the original work is properly cited.

Local climate effects of Tibetan Plateau Ozone Valley (OVTP) were investigated by numerical simulations using Community Atmosphere Model version 5.1.1 (CAM5). After a 20-year spin-up period, two additional 10-year experiments were conducted. CAM5 was driven by monthly mean climatological ozone in control experiment (CE) and OVTP in the sensitivity experiment (SE) was removed from May to September. After the removal of OVTP, South Asian High (SAH) becomes more robust and colder from June to August, especially in June. The reason for enhancement of SAH is that removal of OVTP increasing ozone in 200-30 hPa leads to significant enhancement of longwave and shortwave radiative heating rate in SAH region in June, and then enhancement of horizontal divergence resulting from the radiative warming leads to strengthening of SAH influenced by the Coriolis force, while the colder SAH is primarily caused by dynamic processes. Adiabatic expansion and ascending movement mainly bring about temperature decrease in SAH after OVTP removal, but the thermodynamic process related to radiative heating offsets part of the cooling response.

\section{Introduction}

Ozone layer is an umbrella protecting the Earth and the major heat source of the stratosphere because of absorbing considerable solar ultraviolet radiation [1]. Therefore, ozone depletion could break ecological systems [2] and change the climate [3-6].

However, Molina and Rowland [7] found chlorofluorocarbons thinning the ozone layer and hence ozone depletion attracted much attention. Great ozone loss was found over the South Pole [8] and in the Arctic [9]. Moreover, ozone depletion is not only found near the poles but also found over the middle latitudes. Ozone Valley over the Tibetan Plateau (OVTP) in summer half year in Total Ozone Mapping Spectrometer (TOMS) satellite data was found by Zhou et al. $[10,11]$ and confirmed by Zou [12]. Then Bian et al. [13] reported an ozone low in winter over the Tibetan Plateau (TP) in TOMS datasets. In addition, Guo et al. [14] found another ozone depletion center near $10 \mathrm{hPa}$ over the Tibetan Plateau by the second version of the Stratospheric Aerosol and Gas Experiment (SAGEII). Thereafter, the double-core structure of OVTP was confirmed by Guo et al. [15] in Aura Microwave Limb Sounder (MLS) data. OVTP has a stronger center and weaker center in the upper troposphere and lower stratosphere (UTLS) region and the upper stratosphere, respectively [15].

Some researchers have showed the interaction of ozone and climate change [16-21]. Cai [22] demonstrated the possible link of climate impact of stratospheric ozone depletion to an intensification of the Southern Ocean super-gyre circulation. Cai and Cowan [23] suggested that stratospheric ozone depletion contributes to the observed trend in wind 
stress by model simulation. Polvani et al. [24] found that the most Southern Hemisphere tropospheric circulation changes were caused by polar stratospheric ozone depletion in Twentieth-Century by using the Community Atmospheric Model, version 3 (CAM3). Other studies also suggested that, in addition to greenhouse gas, ozone also contribute to trends in climate forcing by changing the radiative energy budget of the Earth [25] and summertime extratropical circulation trends [26]. Moreover, there were studies that indicated that the climate change also alters the spatial distribution of ozone by influencing the mixing of stratospheric ozone into the troposphere [27, 28]. Meanwhile, a lot of work focused on the mechanism responsible for OVTP after the observational evidence of such ozone depletion. Most of them suggested that dynamic atmospheric transport effect related to the South Asian High (SAH) is the dominated mechanism [14, 29-34]. The role of the large scale circulation on the ozone low was analyzed by Tian et al. [30], Bian et al. [32], Guo et al. [14, 34], Liu et al., and Tian et al. simulated the ozone low and investigated the chemical and dynamic mechanism and pointed out dynamic effect is more important but the latter is weaker $[29,30]$. Terrain effects have something to do not only with the dynamic transportation but also with the column atmosphere loss resulting in column ozone loss [30, 32, 34]. In addition, chemical factors have also been recognized as significant drivers $[15,35]$.

However, the local climate impact of OVTP is still rarely studied, although a minor change of ozone in UTLS region will greatly impact on surface and UV radiation climate [36]. Especially, the major center of OVTP is located in the UTLS region exactly. The OVTP will lead to a zonal asymmetry of radiation forcing which may affect the circulation system of $\mathrm{SAH}$, because SAH is formed and maintained in the UTLS region by the thermal effect of the Tibetan Plateau [37-45].

However, most of the previous studies focus on the effect of SAH on OVTP; less work is concerned about the responses of SAH to OVTP. While a planetary scale circulation system, SAH has an important impact on the climate and weather in the northern hemisphere (Tao and Zhu, 1964; [46-50]). Therefore, in this study we investigate the impact of OVTP on SAH and its mechanism by using the Community Atmosphere Model version 5.1.1 (CAM5). The paper is organized as follows. Model and experiments are described in Section 2. In Section 3, responses of SAH to OVTP are discussed. Mechanism for the responses is analyzed in Section 4, followed by a summary and discussions in Section 5.

\section{Model and Experiments}

CAM5 is the atmospheric component of the Community Earth System Model version 1.0.4 (CESM1). Compared to its predecessors CAM3 and CAM4, substantially revised physical parameterizations are included in CAM5, including an updated radiation scheme [51] which is a key factor for climate modeling $[52,53]$.

In this study, CAM5 with Eulerian dynamical core was used as a standalone model which means the ocean and sea ice components of CESM1 are replaced by annual cycle prescribed data. Horizontal resolution is T42 $\left(2.8^{\circ}\right)$ and hybrid pressure-sigma vertical coordinate has 30 levels with a top at about $3.643 \mathrm{hPa}$.

After a 20-year spin-up period, two additional 10-year experiments were conducted and analyzed in this paper. In the control experiment (CE), CAM5 was driven by monthly mean climatological ozone. In the sensitivity experiment (SE), every ozone value in the domain $\left(30-120^{\circ} \mathrm{E}, 0-60^{\circ} \mathrm{N}\right)$ from May to September was set to the zonal mean of corresponding latitude so that OVTP could be considered removed approximately. The two experiments are identical in all aspects to the configurations except the ozone distribution; thus the comparison between CE and SE run can be made to identify the influence of OVTP to SAH.

\section{Response of SAH to OVTP}

OVTP is removed, which is showed in Figures 1(a)-1(e), in order to investigate the impact of OVTP on SAH. OVTP exists during May to September (Figures 1(a)-1(e)) and even becomes ozone low center in August and September (Figures 1(d)-1(e)) in CE, while ozone contours are exactly parallel to meridional direction over the Tibetan Plateau region $\left(30-120^{\circ} \mathrm{E}, 0-60^{\circ} \mathrm{N}\right.$ ) in SE (Figures $1(\mathrm{a})-1(\mathrm{e})$ ). The differences of ozone between the two experiments (SE-CE) show that the center of ozone difference by more than $3 \times 10^{-7} \mathrm{~mol} / \mathrm{mol}$ is over the Tibet Plateau in May (Figure 1(a)) and extends to the west in June (Figure 1(b)) and then maintains over the Iranian Plateau from July to September with the intensity of no more than $3 \times 10^{-7} \mathrm{~mol} / \mathrm{mol}$ (Figures $1(\mathrm{c})-1(\mathrm{e})$ ).

After the removal of the OVTP, significant strengthening of SAH only happens from June to August (Figures $1(\mathrm{~g})-1(\mathrm{i})$ ), especially in the center of SAH in June (Figure $1(\mathrm{~g})$ ), which is indicated by the difference of the geopotential height between the two experiments (Figures $1(\mathrm{f})-1(\mathrm{j})$ ). In June, the strengthening center of SAH is located in $56^{\circ} \mathrm{E}$ and $40^{\circ} \mathrm{N}$ and the change is up to more than $30 \mathrm{gpm}$ which satisfies the significance test at the $80 \%$ confidence level (Figure $1(\mathrm{~g})$ ), while strengthening intensity of SAH becomes week in July (Figure 1(h)) and August (Figure 1(i)). The significant change of geopotential height about $15 \mathrm{gpm}$ happens near the east center of SAH $\left(90^{\circ} \mathrm{E}\right.$ and $\left.40^{\circ} \mathrm{N}\right)$ in July. By August, the strengthening region is located in the center of $\mathrm{SAH}$ $\left(50^{\circ} \mathrm{E}\right.$ and $\left.38^{\circ} \mathrm{N}\right)$ and extends to the northeast part of $\mathrm{SAH}$ (Figure 1(i)). And there are no significant changes of SAH in May (Figure 1(f)) and September (Figure 1(j)). On the whole, the responses of SAH to OVTP are mainly in June.

The response of temperature to OVTP is not significant in $70 \mathrm{hPa}$ (Figures $1(\mathrm{k})-1(\mathrm{o})$ ), and the pattern of the temperature response is opposite to that of the geopotential height response (Figures 1(f)-1(o)). From June to August, SAH significantly strengthens after the removal of OVTP (Figures $1(\mathrm{~g})-1(\mathrm{i}))$. Meanwhile, the negative temperature responses are just located in the position where significant positive changes of the geopotential height happen from June to August (Figures 1(g)-1(i)).

In summary, after the removal of OVTP, SAH becomes more robust and colder in $70 \mathrm{hPa}$ from June to August, especially in June. 


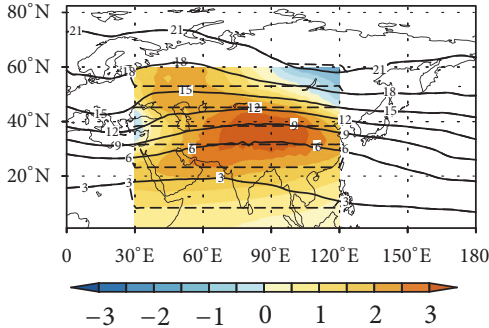

(a)

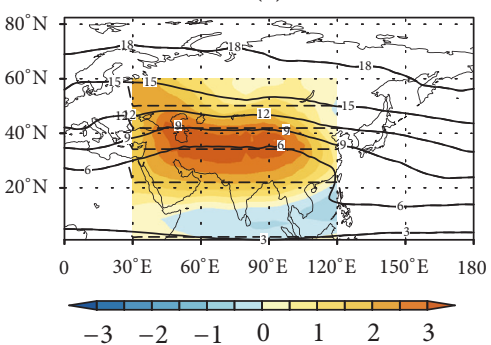

(b)

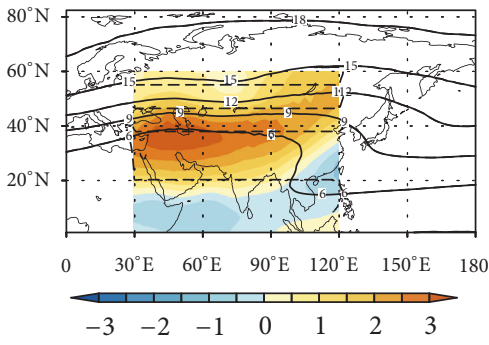

(c)

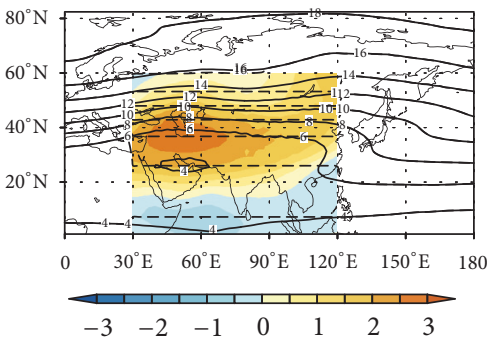

(d)

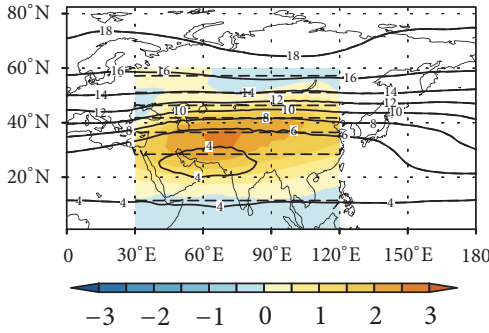

(e)

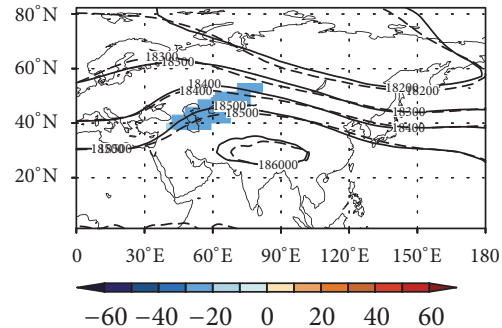

(f)

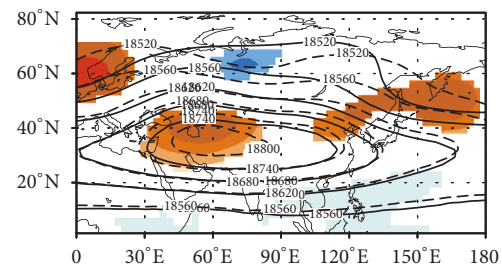

$-60-40-20 \quad 0 \quad 20 \quad 40 \quad 60$

(g)

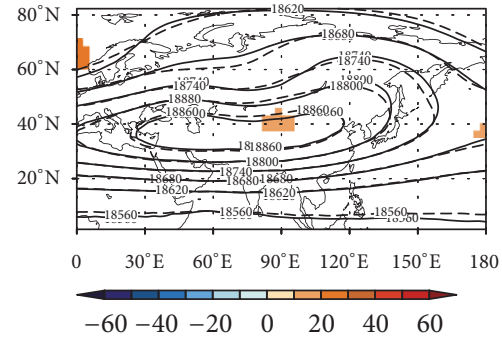

(h)

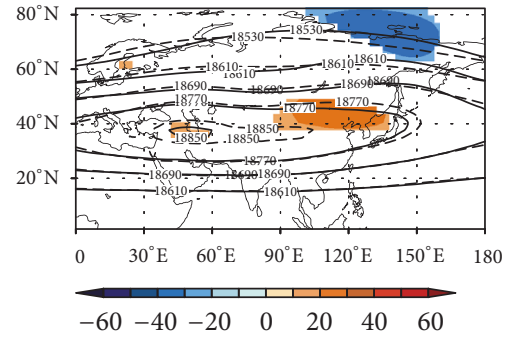

(i)

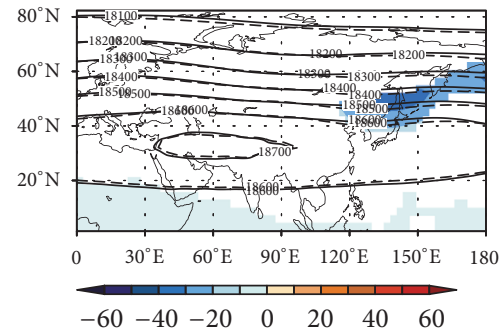

(j)

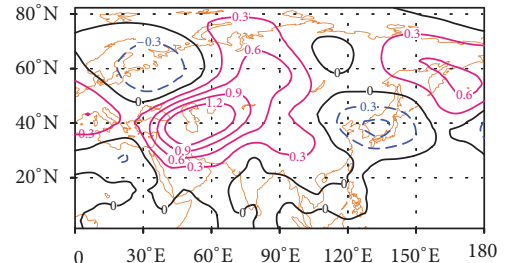

(k)

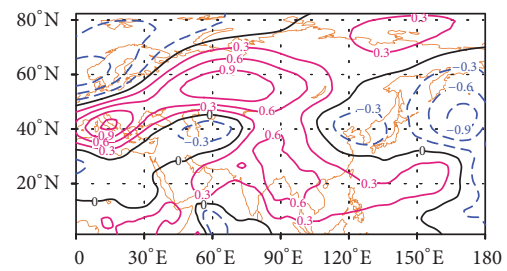

(1)

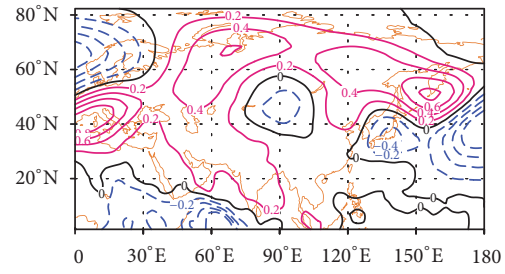

(m)

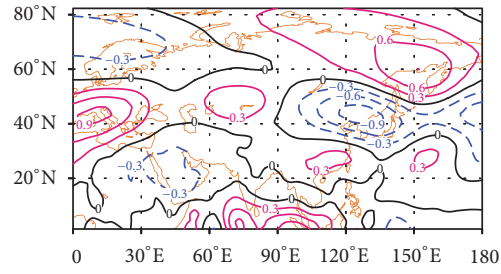

(n)

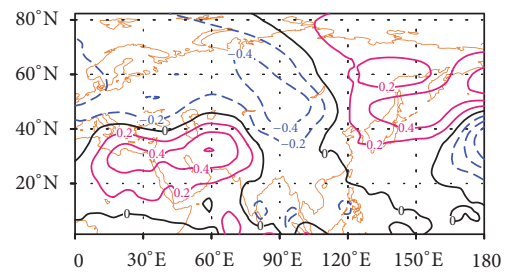

(o)

FIGURE 1: Ozone in CE (solid contour) and in SE (dashed contour) and difference of ozone between two experiments (SE-CE, shaded) at $70 \mathrm{hPa}$ from May to September ((a-e), units: $\left.10^{-7} \mathrm{~mol} / \mathrm{mol}\right) ;(\mathrm{f}-\mathrm{j})$ same as (a-e) but for zonal deviation of geopotential height (units: gpm, values in shaded area exceeding $80 \%$ confidence level). Difference of temperature zonal deviation between two experiments (SE-CE) at $70 \mathrm{hPa}$ from May to September ((k-o), units: K). 


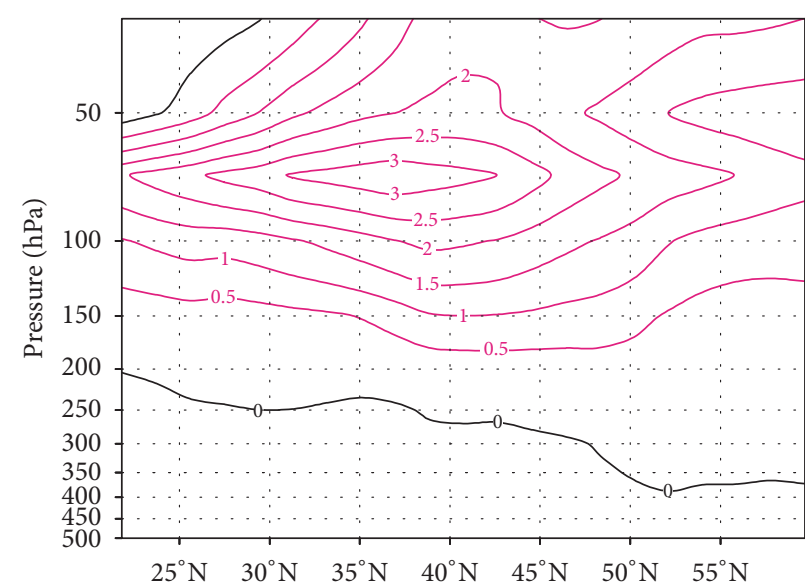

(a)

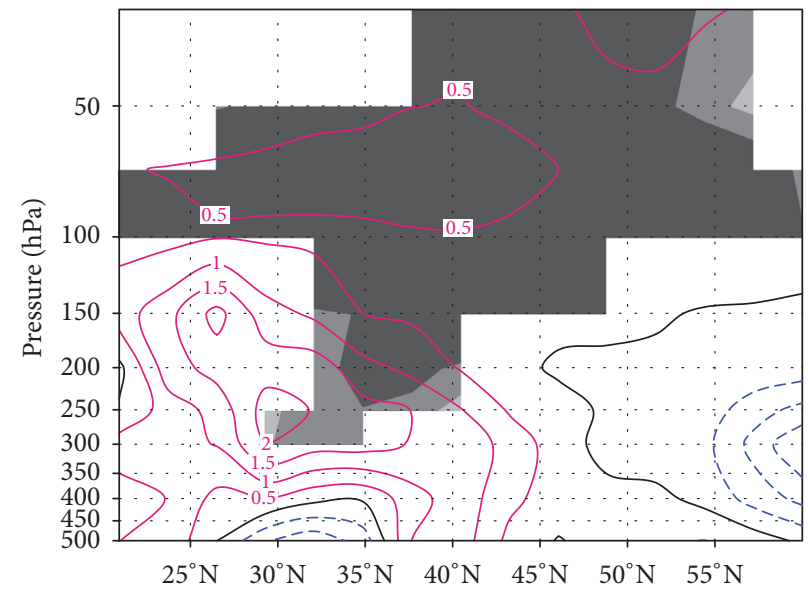

(c)

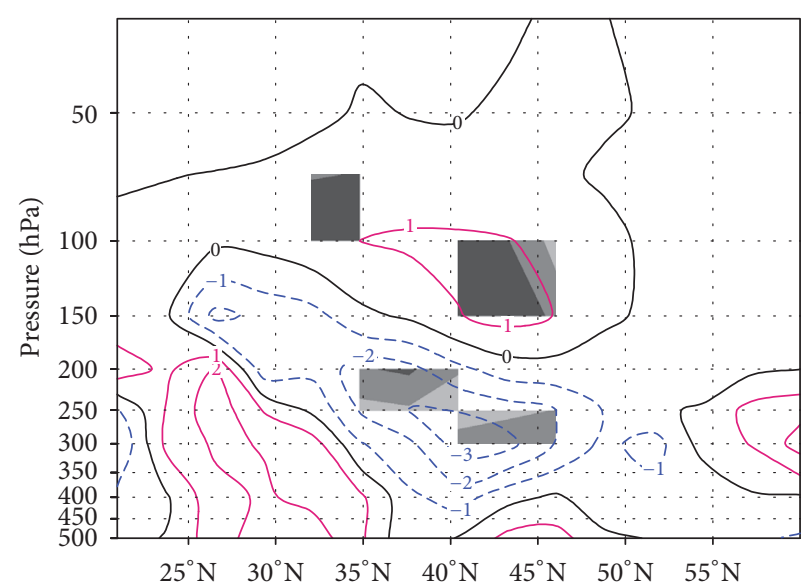

(b)

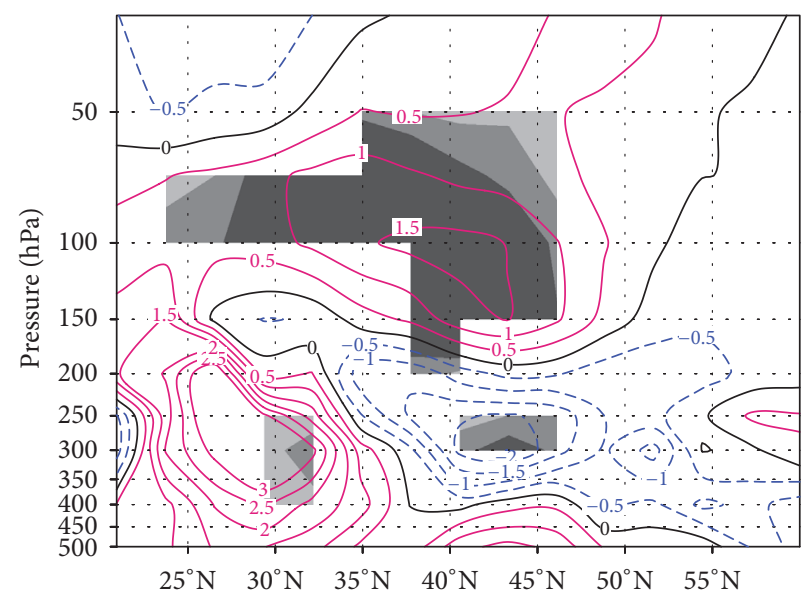

(d)

FIGURE 2: Vertical-latitude cross section of ozone ((a), units: $\left.10^{-7} \mathrm{~mol} / \mathrm{mol}\right)$, longwave heating rate ((b), units: $\left.10^{-6} \mathrm{~K} / \mathrm{s}\right)$, shortwave heating rate $\left((\mathrm{c})\right.$, units: $\left.10^{-6} \mathrm{~K} / \mathrm{s}\right)$, and net radiative heating rate $\left((\mathrm{d})\right.$, units: $\left.10^{-6} \mathrm{~K} / \mathrm{s}\right)$ difference between two experiments (SE-CE) along $56^{\circ} \mathrm{E}$ in June (shaded values from light to dark exceeding 90\%, 95\%, and 99\% confidence level, resp.).

\section{Mechanism for the Responses}

4.1. Mechanism for SAH Enhancement. Vertical-latitude cross sections of difference between two experiments along $56^{\circ} \mathrm{E}$ in June are showed (Figures 2-4), because the most obvious response of SAH to OVTP happens in $56^{\circ} \mathrm{E}$ and $40^{\circ} \mathrm{N}$ in June (Figure $1(\mathrm{~g})$ ). Heating rates of longwave and shortwave radiation are used to analyze thermodynamic process first, and then dynamic process is analyzed by using horizontal divergence and vertical velocity.

Removal of OVTP increasing ozone in $200-30 \mathrm{hPa}$ leads to significant enhancement of radiative heating rate in $\mathrm{SAH}$ region in June (Figure 2). It causes an increase of ozone from $200 \mathrm{hPa}$ to $30 \mathrm{hPa}$, and the peak value is about $3 \times$ $10^{-7} \mathrm{~mol} / \mathrm{mol}$ at $70 \mathrm{hPa}$ (Figure $2(\mathrm{a})$ ). At the same time, shortwave heating rate and longwave heating rate both strengthen significantly in the region where positive ozone change happens, because ozone can absorb shortwave radiation and longwave radiation. The longwave heating rate increases (decreases) significantly by $1 \times 10^{-6} \mathrm{~K} / \mathrm{s}$ from $100 \mathrm{hPa}$ to $50 \mathrm{hPa}$ (below $200 \mathrm{hPa}$, Figure 2(b)), and the shortwave heating rate increases significantly by $5 \times 10^{-7} \mathrm{~K} / \mathrm{s}$ from $100 \mathrm{hPa}$ to $50 \mathrm{hPa}$ where the ozone increases most (Figure 2(c)), which indicates that the absorption of the solar ultraviolet radiation increases with the ozone increase in this region. Thus, the sum of longwave heating rate and shortwave heating rate increases (decreases) significantly by $1.5 \times 10^{-6} \mathrm{~K} / \mathrm{s}\left(2 \times 10^{-6} \mathrm{~K} / \mathrm{s}\right)$ above (below) $200 \mathrm{hPa}$ (Figure 2(d)) which exceeds $90 \%$ confidence level. That is to say, the total effect of longwave and shortwave radiation is to warm (cool) the atmosphere in (under) $\mathrm{SAH}$ region in June.

Enhancement of horizontal divergence resulting from radiative warming in $\mathrm{SAH}$ region leads to strengthening of $\mathrm{SAH}$ influenced by the Coriolis force (Figure 3 ). The response of horizontal divergence (convergence) strengthens above (below) $300 \mathrm{hPa}$ (Figure 3(a)). With the change of horizontal divergence, SAH strengthens significantly from $500 \mathrm{hPa}$ to $30 \mathrm{hPa}$ with a positive center of more than $60 \mathrm{gpm}$ at $200 \mathrm{hPa}$ 


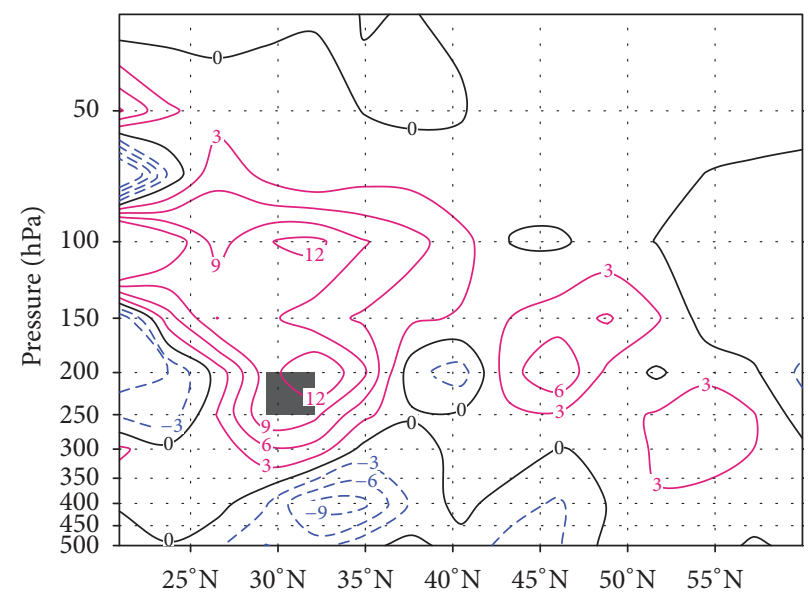

(a)

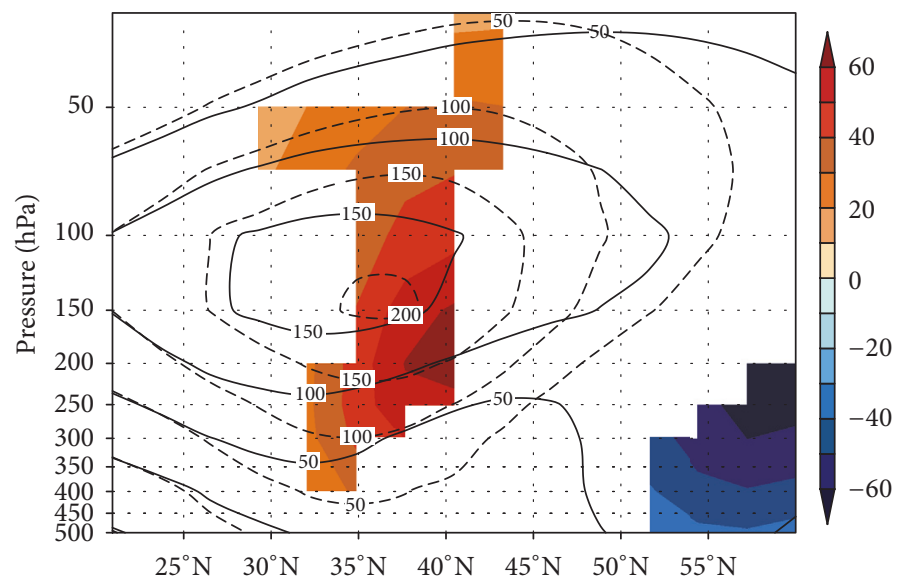

(b)

Figure 3: (a) is the same as Figure 2, but for horizontal divergence (units: $10^{-7} / \mathrm{s}$ ) and shaded values that are exceeding $80 \%$ confidence level; (b) is the same as Figure 1(g), but for vertical-latitude cross section along $56^{\circ} \mathrm{E}$ and shaded values that are exceeding $95 \%$ confidence level.

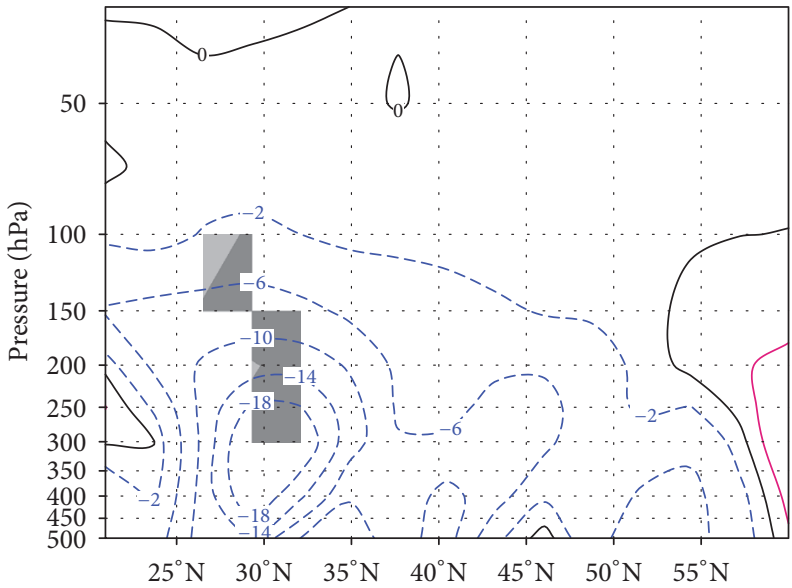

(a)

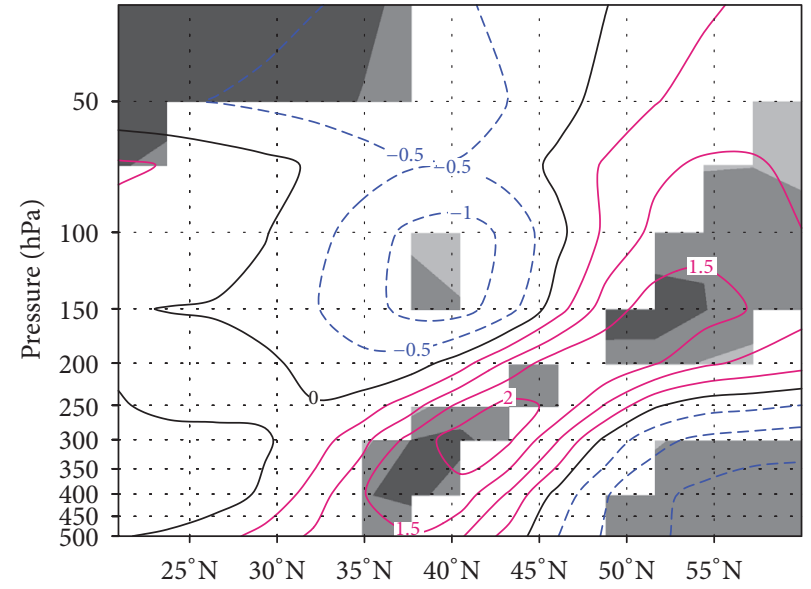

(b)

FIgURE 4: The same as Figure 2, but for vertical velocity ((a), units: $\left.10^{-3} \mathrm{~Pa} / \mathrm{s}\right)$ and for zonal deviation of temperature ((b), units: K).

in the north of the center of SAH, and the difference between two experiments satisfies the significance test at the $90 \%$ confidence level (Figure 3(b)).

To sum up, removal of OVTP increasing ozone in 200-30 hPa leads to significant enhancement of longwave and shortwave radiative heating rate in $\mathrm{SAH}$ region in June, and then enhancement of horizontal divergence resulting from the radiative warming leads to strengthening of SAH influenced by the Coriolis force.

4.2. Mechanism for Colder SAH. The analysis of radiative heating (Figure 2) suggests that there should be a warmer SAH after the OVTP removal, but the previous analysis indicates that the strengthening region of SAH corresponds to the cooling at $70 \mathrm{hPa}$ (Figures $1(\mathrm{~g})$ and $1(\mathrm{i})$ ). Therefore, there should be another cooling mechanism rather than thermodynamic process. Air expanding could be the main reason for cooling, because enhancement area of divergence area (Figure 3(a)) agrees with that of the negative response of temperature (Figure 4(b)). Moreover, cooling in higher level and heating in lower level (Figures 2(d) and 4(b)) cause the atmospheric stratification trend to be more unstable, which promotes the ascending movement (Figure 4(a)). With the strengthening of ascending movement, air expands adiabatically and eventually causes more cooling in this region. Consequently, dynamic process related to adiabatic expansion and ascending movement mainly brings about temperature decrease in SAH after OVTP removal, but the thermodynamic process related to radiative heating offsets the cooling response. 


\section{Summary and Discussions}

The local climate effects of OVTP were analyzed by using the CAM5, in which OVTP is removed approximately. The results are as follows:

(1) After the removal of OVTP, SAH becomes more robust and colder from June to August, especially in June.

(2) Removal of OVTP increasing ozone in $200-30 \mathrm{hPa}$ leads to significant enhancement of longwave and shortwave radiative heating rate in $\mathrm{SAH}$ region in June, and then enhancement of horizontal divergence resulting from the radiative warming leads to strengthening of SAH influenced by the Coriolis force.

(3) Dynamic process related to adiabatic expansion and ascending movement mainly brings about temperature decreases in SAH after OVTP removal, but the thermodynamic process related to radiative heating offsets part of the cooling response.

The removal of OVTP has a significant effect on SAH as mentioned above based on the numerical simulations, but OVTP change in this paper is much larger than natural variability of OVTP. Therefore, the response of SAH to natural variability of OVTP by using CAM5 in the future is worth studying. Moreover, the anomaly of the interaction between stratosphere and troposphere caused by OVTP is another interesting issue, which may induce the amomaly of Rossby-Wave Propagation [54, 55].

\section{Conflicts of Interest}

The authors declare that they have no conflicts of interest.

\section{Acknowledgments}

The provision of CAM5 by NCEP is gratefully acknowledged. This study was supported by the National Natural Science Foundation of China (41641042, 41375092, 91537213, 41675039, 41375047, and 41175081) and Priority Academic Program Development of Jiangsu Higher Education Institutions (PAPD).

\section{References}

[1] D. G. Andrews, J. R. Holton, and C. B. Leovy, Middle Atmosphere Dynamics, vol. 127, Academic Press, Massachusetts, Mass, USA, 1983.

[2] J. Fuhrer and F. Booker, "Ecological issues related to ozone: agricultural issues," Environment International, vol. 29, no. 2-3, pp. 141-154, 2003.

[3] C. McLandress, T. G. Shepherd, J. F. Scinocca et al., "Separating the dynamical effects of climate change and ozone depletion. Part II: Southern Hemisphere troposphere," Journal of Climate, vol. 24, no. 6, pp. 1850-1868, 2011.

[4] S.-K. Min and S.-W. Son, "Multimodel attribution of the Southern Hemisphere Hadley cell widening: Major role of ozone depletion," Journal of Geophysical Research Atmospheres, vol. 118 , no. 7, pp. 3007-3015, 2013.

[5] WMO, "Scientific Assessment of Ozone Depletion: 201," WMO Global Ozone Research and Monitoring Project Report No. 55, pp.4.19-4.45, 2014.

[6] World Meteorological Organisation, Weather and Climate: Understanding Risks and Preparing for Variability and Extremes, vol. 63, WMO Bulletin, Geneva, Switzerland, 2014.

[7] M. J. Molina and F. S. Rowland, "Stratospheric sink for chlorofluoromethanes: chlorine atom-catalysed destruction of ozone," Nature, vol. 249, no. 5460, pp. 810-812, 1974.

[8] J. C. Farman, B. G. Gardiner, and J. D. Shanklin, "Large losses of total ozone in Antarctica reveal seasonal ClOx/NOx interaction," Nature, vol. 315, no. 6016, pp. 207-210, 1985.

[9] P. A. Newman, J. F. Gleason, R. D. McPeters, and R. S. Stolarski, "Anomalously low ozone over the Arctic," Geophysical Research Letters, vol. 24, no. 22, pp. 2689-2692, 1997.

[10] X. Zhou and C. Luo, "Ozone valley over Tibetan Plateau," Annual Report of CAMS, vol. 8, no. 4, pp. 505-506, 1994.

[11] X. Zhou, C. Luo, W. Li et al., "Total ozone variation in China and ozone low over Tibetan Plateau," Chinese Science Bulletin, vol. 40, no. 15, pp. 1396-1398, 1995 (Chinese).

[12] H. Zou, "Seasonal variation and trends of Toms ozone over Tibet," Geophysical Research Letters, vol. 23, no. 9, pp. 1029-1032, 1996.

[13] J. Bian, G. Wang, H. Chen, D. Qi, D. Lü, and X. Zhou, "Ozone mini-hole occurring over the Tibetan Plateau in December 2003," Chinese Science Bulletin, vol. 51, no. 7, pp. 885-888, 2006.

[14] D. Guo, P. Wang, X. Zhou, Y. Liu, and W. Li, "Dynamic effects of the South Asian high on the ozone valley over the Tibetan Plateau," Acta Meteorologica Sinica, vol. 26, no. 2, pp. 216-228, 2012.

[15] D. Guo, Y. Su, C. Shi, J. Xu, and A. M. Powell, "Double core of ozone valley over the Tibetan Plateau and its possible mechanisms," Journal of Atmospheric and Solar-Terrestrial Physics, vol. 130, no. 8, pp. 127-131, 2015.

[16] M. Shiotani, "Annual, quasi-biennial, and El Niño-Southern Oscillation (ENSO)time-scale variations in equatorial total ozone," Journal of Geophysical Research, vol. 97, no. D7, p. 7625, 1992.

[17] W. J. Randel, R. R. Garcia, N. Calvo, and D. Marsh, "ENSO influence on zonal mean temperature and ozone in the tropical lower stratosphere," Geophysical Research Letters, vol. 36, no. 15, Article ID L15822, 2009.

[18] L. D. Oman, J. R. Ziemke, A. R. Douglass et al., "The response of tropical tropospheric ozone to ENSO," Geophysical Research Letters, vol. 38, no. 13, Article ID L13706, 2011.

[19] F. Xie, J. Li, W. Tian, J. Zhang, and C. Sun, “The relative impacts of El Niño Modoki, canonical El Niño, and QBO on tropical ozone changes since the 1980s," Environmental Research Letters, vol. 9, no. 6, Article ID 064020, 2014.

[20] F. Xie, J. Li, W. Tian et al., "A connection from Arctic stratospheric ozone to El Niño-Southern oscillation," Environmental Research Letters, vol. 11, no. 12, Article ID 124026, 2016.

[21] C. Li, S. Guo, Q. Qi Yi, and H. Li, "Relationship between atmospheric ozone and polar vortex intensity in the mid-high latitude over the northern hemisphere in winter," Meteorology, vol. 35, no. 5, pp. 1290-1297, 2016. 
[22] W. Cai, "Antarctic ozone depletion causes an intensification of the Southern Ocean super-gyre circulation," Geophysical Research Letters, vol. 33, no. 3, Article ID L03712, 2006.

[23] W. Cai and T. Cowan, "Trends in Southern Hemisphere circulation in IPCC AR4 models over 1950-99: ozone depletion versus greenhouse forcing," Journal of Climate, vol. 20, no. 4, pp. 681693, 2007.

[24] L. M. Polvani, D. W. Waugh, G. J. P. Correa, and S.-W. Son, "Stratospheric ozone depletion: The main driver of twentiethcentury atmospheric circulation changes in the Southern Hemisphere," Journal of Climate, vol. 24, no. 3, pp. 795-812, 2011.

[25] G. Myhre, D. Shindell, F.-M. Brèon, W. Collins, J. Fuglestvedt, J. Huang et al., "Anthropogenic and natural radiativeforcing," in Climate Change 2013: The Physical Science Basis. Contribution of Working Group I to the Fifth Assessment Report of the Intergovernmental Panelon Climate Change, T. F. Stocker, D. Qin, G.-K. Plattner, M. Tignor, S. K. Allen, J. Boschung et al., Eds., Cambridge University Press, New York, NY, USA, 2013.

[26] S. Lee and S. B. Feldstein, "Detecting ozone- and greenhouse gas-driven wind trends with observational data," Science, vol. 339, no. 6119, pp. 563-567, 2013.

[27] M. I. Hegglin and T. G. Shepherd, "Large climate-induced changes in ultraviolet index and stratosphere-to- troposphere ozone flux," Nature Geoscience, vol. 2, no. 10, pp. 687-691, 2009.

[28] L. L. Pan, C. R. Homeyer, S. Honomichl et al., "Thunderstorms enhance tropospheric ozone by wrapping and shedding stratospheric air," Geophysical Research Letters, vol. 41, no. 22, pp. 7785-7790, 2015.

[29] Y. Liu, W. Li, X. Zhou, and J. He, "Mechanism of formation of the ozone valley over the Tibetan Plateau in summer - Transport and chemical process of ozone," Advances in Atmospheric Sciences, vol. 20, no. 1, pp. 103-109, 2003.

[30] W. Tian, M. Chipperfield, and Q. Huang, "Effects of the Tibetan Plateau on total column ozone distribution," Tellus, Series B: Chemical and Physical Meteorology, vol. 60, no. 4, pp. 622-635, 2008.

[31] Y. Liu, Y. Wang, X. Liu, Z. Cai, and K. Chance, “Tibetan middle tropospheric ozone minimum in June discovered from GOME observations," Geophysical Research Letters, vol. 36, Article ID L05814, 2009.

[32] J. Bian, R. Yan, H. Chen, D. Lü, and S. T. Massie, "Formation of the summertime ozone valley over the Tibetan Plateau: the Asian summer monsoon and air column variations," Advances in Atmospheric Sciences, vol. 28, no. 6, pp. 1318-1325, 2011.

[33] Y. Su, D. Guo, and S. Guo, "Trends of ozone over the Tibetan Plateau in the next 100 years and their possible mechanism," Trans. Atmos. Sci, vol. 39, pp. 309-317, 2016.

[34] D. Guo, Y. Su, X. Zhou et al., "Evaluation of the trend uncertainty in summer ozone valley over the Tibetan Plateau in three reanalysis datasets," Journal of Meteorological Research, vol. 31, no. 2, pp. 431-437, 2017.

[35] Y. Liu, W. Li, and X. Zhou, "A possible effect of heterogeneous reactions on the formation of ozone valley over the Tibetan Plateau," Acta Meteorologica Sinica, vol. 68, no. 6, pp. 836-846, 2010.

[36] G. Li, D. R. Lü, and X. X. Tie, "The impact of tropopause variation on ozone distribution in upper troposphere/lower stratosphere," Chinese Journal of Space Science, vol. 23, no. 4, pp. 269-277, 2003.
[37] H. Flohn, "Recent investigation in the mechanism of the summer monsoon of southern and eastern Asia," in Proceedings of the Symposium on Monsoons of the World, pp. 75-88, Hind Union Press, New Delhi, India, 1960.

[38] D. Ye, "Some characteristics of the summer circulation over the Qinghai-Xizang (Tibet) plateau and its neighborhood," Bulletin of the American Meteorological Society, vol. 62, no. 1, pp. 14-19, 1981.

[39] T. C. Yeh, "Some aspects of the thermal influences of the Qinghai-Tibetan plateau on the atmospheric circulation," Archives for Meteorology, Geophysics, and Bioclimatology Series A, vol. 31, no. 3, pp. 205-220, 1982.

[40] R. H. Huang, "Effect of abnormal heat sources over Tibetan Plateau on general circulation anomalies of summer in the Northern Hemisphere," Acta Meteorologica Sinica, vol. 43, no. 2, pp. 208-220, 1985 (Chinese).

[41] G. X. Wu, W. P. Li, H. Guo et al., "Thermal air pumps and the asian summer monsoon on the tibetan plateau," in Zhao Jiuzhang's 90th Anniversary Collection, pp. 116-120, Science press, Beijing, China, 1997.

[42] Q. M. Liu, G. X. Wu, H. Liu et al., "The effect of spatially nonuniform heating on the formation and variation of subtropical high part III: condensation heating and South Asia High and western Pacific Subtropical High," Acta Meteorologica Sinica, vol. 57, no. 5, pp. 525-538, 1999.

[43] A. M. Duan and G. X. Wu, "Role of the Tibetan Plateau thermal forcing in the summer climate patterns over subtropical Asia," Climate Dynamics, vol. 24, no. 7-8, pp. 793-807, 2005.

[44] B. Q. Liu, J. H. He, and L. J. Wang, "Characteristics of the South Asia High establishment processes above the Indo-China Peninsula from April to May and their possible mechanism," Chinese Journal of Atmospheric Sciences, vol. 33, no. 6, pp. 13191332, 2009.

[45] X. J. Zhou, P. Zhao, J. M. Chen, L. Chen, and W. Li, "Impacts of thermodynamic processes over the Tibetan Plateau on the Northern Hemispheric climate," Science in China Series D: Earth Sciences, vol. 52, no. 11, pp. 1679-1693, 2009.

[46] S. Luo, Z. Qian, and Q. Wang, "The climatic and synoptical study about the relation between the Qinghai-Xizang high pressure on the $100 \mathrm{mb}$ surface and the flood and drought in east china in summer," Plateau Meteorology, vol. 1, no. 2, pp. 110, 1982.

[47] S. Y. Tao and L. X. Chen, "A review of recent research on the East Asian Summer Monsoon in China," Monsoon Meteorology, vol. 7, pp. 60-92, 1987.

[48] Q. Zhang and G. Wu, "The large area flood and drought over Yangtze river valley and its relation to the South Asia High," Acta Meteorologica Sinica, vol. 59, no. 5, pp. 569-577, 2001.

[49] Y. Huang and Y. F. Qian, "Relationships between South Asian High and summer rainfall in North China," Plateau Meteorology, vol. 22, no. 6, pp. 602-607, 2003.

[50] J. Hu and J. Bei, "Comparative analysis of the relation between characteristic parameters of South Asia High and summer precipitation of China," Meteorological Monthly, vol. 36, no. 4, pp. 51-56, 2010.

[51] M. J. Iacono, J. S. Delamere, E. J. Mlawer, M. W. Shephard, S. A. Clough, and W. D. Collins, "Radiative forcing by long-lived greenhouse gases: calculations with the AER radiative transfer models," Journal of Geophysical Research D: Atmospheres, vol. 113, no. 13, Article ID D13103, 2008. 
[52] F. Zhang, Y.-N. Shi, J. Li, K. Wu, and H. Iwabuchi, "Variational iteration method for infrared radiative transfer in a scattering medium," Journal of the Atmospheric Sciences, vol. 74, no. 2, pp. 419-430, 2017.

[53] F. Zhang, K. Wu, P. Liu, X. Jing, and J. Li, "Accounting for Gaussian quadrature in four-stream radiative transfer algorithms," Journal of Quantitative Spectroscopy and Radiative Transfer, vol. 192, pp. 1-13, 2017.

[54] C. Shi, T. Xu, D. Guo, and Z. Pan, "Modulating effects of planetary wave 3 on a stratospheric sudden warming event in 2005," Journal of the Atmospheric Sciences, vol. 74, no. 5, pp. 1549-1559, 2017.

[55] C. Shi, T. Xu, H. Li, and Y. Gao, "The Role of RossbyWave Propagation in a North American Extreme Cold Event," Advances in Meteorology, vol. 2017, pp. 1-10, Article ID 4635849, 2017. 

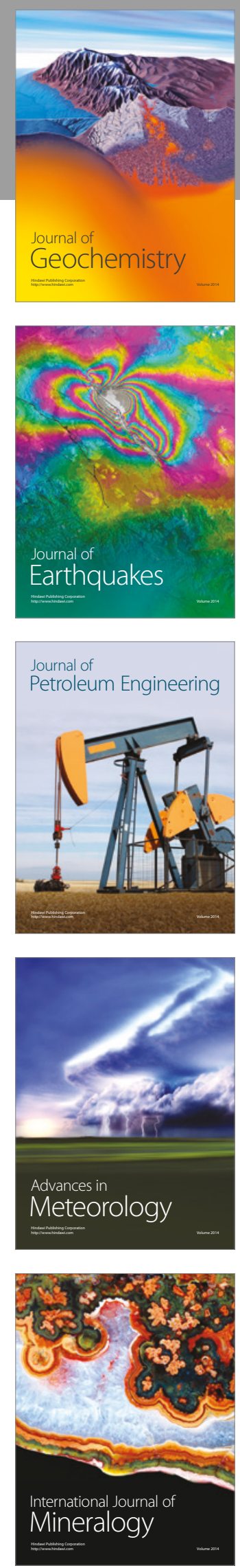
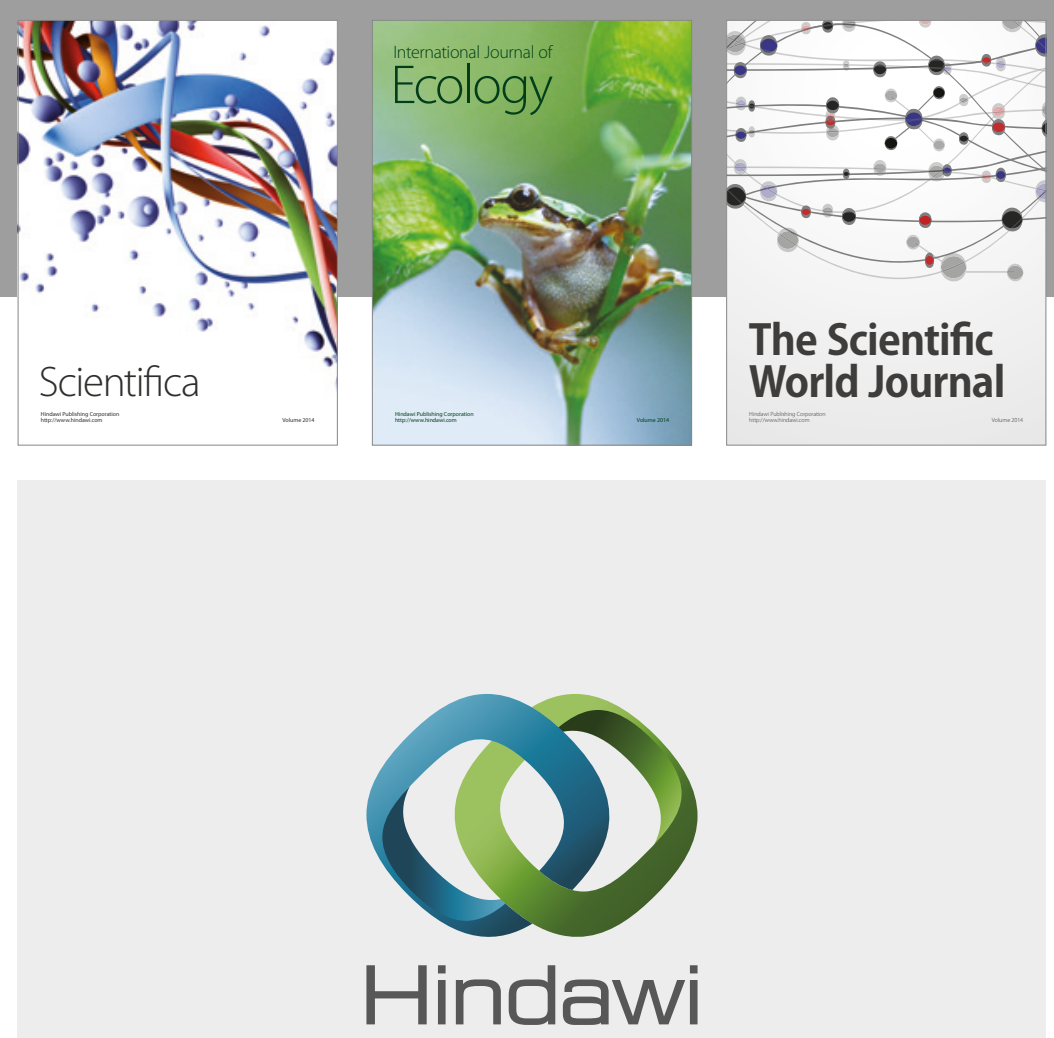

Submit your manuscripts at

https://www.hindawi.com
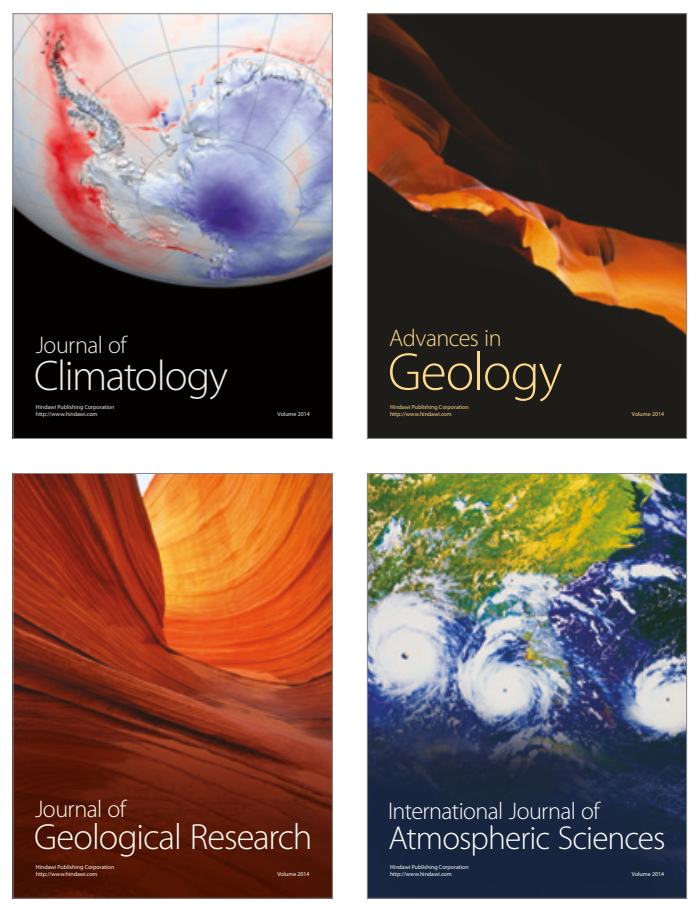

The Scientific

World Journal
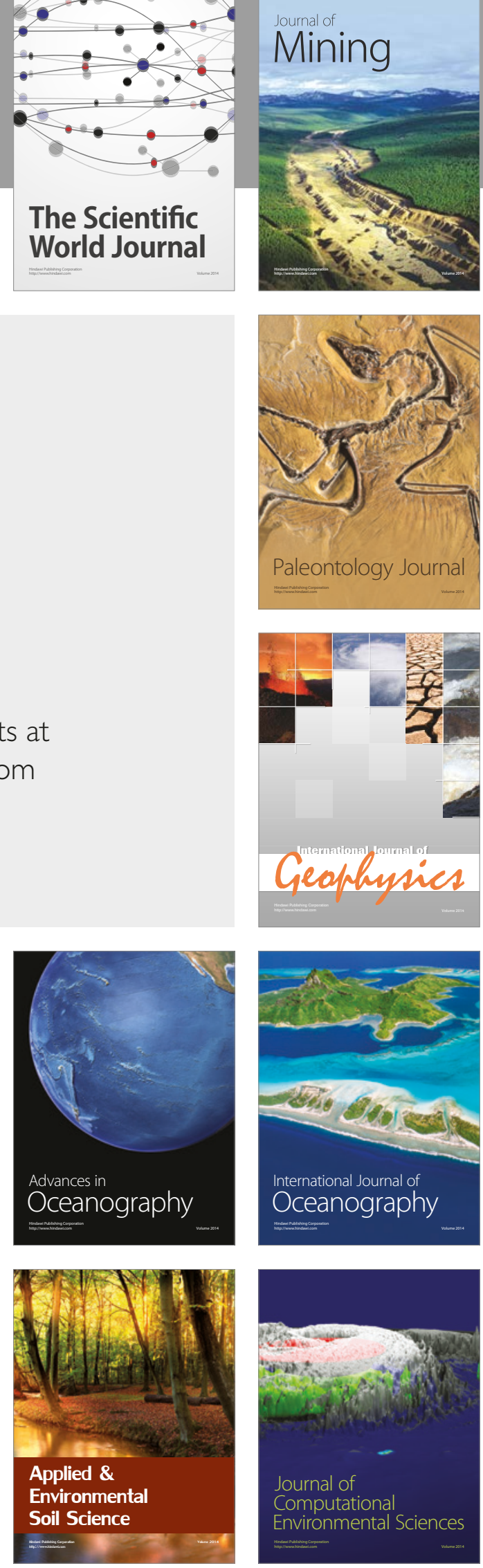